\title{
Estimation of Total Phenol, Flavonoid, Tannin and Alkaloid Content in Different Extracts of Catharanthus roseus from Durg District, Chhattisgarh, India
}

\author{
Rajeshwari Prabha Lahare ${ }^{1}$, Hari Shankar Yadav ${ }^{2 *}$, Yogesh Kumar Bisen ${ }^{3}$ and Anil Kumar Dashahre ${ }^{4}$ \\ ${ }^{1}$ Research scholar, Department of Biotechnology Govt. Science College, Durg (C.G.), India \\ ${ }^{2}$ Uchh Madhyamik Shikshak, Govt. H.S. School Nikkum (Birsa), Balaghat, Madhya Pradesh, India \\ ${ }^{3}$ Department of Biological Science, Rani Durgavati University, Jabalpur, Madhya Pradesh, India 482001 \\ ${ }^{4}$ National Tiger Conservation Authority Regional Office Ravinagar, Nagpur, Maharashtra, India
}

DOI: $10.36348 / \mathrm{sb} .2021 . v 07 i 01.001$

| Received: 16.12.2020 | Accepted: 31.12.2020 | Published: 05.01.2021

*Corresponding author: Dr. Hari Shankar Yadav

\section{Abstract}

Catharanthus rosea is an important ethno medicinal plant rich in bioactive compounds mainly alkaloids used widely in treatment of cancer disease. The aim of present study was to determine the total phenol, flavonoid, tannin and alkaloid content in leaf stem and root parts of Catharanthus rosea in benzene, methanol, aqueous, chloroform and petroleum ether extracts by spectrophotometric method. Phytochemical analysis showed presence of saponin, tannin, terpenoid, flavonoid, cardiac glycoside, alkaloid, steroid, quinones and phenolic compounds whereas protein was found absent. The total phenol, flavonoid, tannin, and alkaloid content of plant in different extracts were determined in comparison to standard gallic acid, rutin, tannic acid and quercetin respectively. The higher concentration for phenol was found in benzene leaf extract $(0.65 \pm 0.02) \mu \mathrm{g} / \mathrm{ml}$, flavonoid in chloroform leaf extract $(0.62 \pm 0.02) \mu \mathrm{g} / \mathrm{ml}$, tannin in methanol root extract $(21 \pm 0.01) \mu \mathrm{g} / \mathrm{ml}$ and alkaloid in benzene leaf extract $(0.61 \pm 0.03) \mu \mathrm{g} / \mathrm{ml}$. The presence of such metabolites indicates therapeutic importance of plant.

Keywords: Phenol, flavonoids, Tannin, Alkaloids, Catharanthus Roseus.

Copyright (C) 2021 The Author(s): This is an open-access article distributed under the terms of the Creative Commons Attribution 4.0 International License (CC BY-NC 4.0) which permits unrestricted use, distribution, and reproduction in any medium for non-commercial use provided the original author and source are credited.

\section{INTRODUCTION}

Catharanthus roseus (L.) is annual, herbaceous, evergreen; dicotyledonous angiosperm plant belongs to family Apocynaceae. Leaves of the plant are $2.5-9.0 \mathrm{~cm}$. long and $1-3.5 \mathrm{~cm}$ broad, hairless, glossy, and green in color and midrib is pale and shape is oval to oblong, petiole is short about 1-1.8 $\mathrm{cm}$ long and they are appositively arranged in pairs. The flowers are dark white or pink with dark red in centre. The plant is popularly known as Nayantara, Sadabahar and Madagascar periwinkle because it is endemic to Madagascar. The synonyms of plant include Lochnera rosea, Ammocallis rosea, Rosy Periwinkle Cape Periwinkle, Rose Periwinkle and "Old Maid". The plant has two common cultivars which are differentiated based on their flower color "Rosea" for pink flower and "Alba" for white flowers. Alkaloid is the main bioactive molecule of plant used for the treatment of diabetes, blood pressure, menstrual problem, asthma, constipation, and cancer. The plant is cultivated mainly for its alkaloids, which are having anticancer activities
[1]. More than 100 monoterpenoids indole alkaloids (TIA) were found in different parts of plant [2]. Leaves and stems are the main sources of vinacristine and vinblastine which act against cancer, while roots have antihypertensive, ajmalicine and serpentine [3]. The ariel parts of the plant contain alkaloids like vindesine, vindeline tabersonine, vinblastine, vincristine, actineoplastidemeric whereas, raubasin, reserpine, catharanthine, vinceine, vineamine, and ajmalicine are present in basal or root parts of the plant. Ajmalicine was isolated from Catharanthus roseus showed depressor action on arterial blood pressure. The leaves are used traditionally in various regions of the world including India, West Indies as well as Nigeria to control diabetes [4]. The leaves have been known to contain 150 useful alkaloids among other pharmacologically active compounds. Significant antihyperglycemic and hypotensive activity of the leaf extracts (hydroalcoholic or dichloromethane-methanol) have been reported in laboratory animals [5]. Fresh leaf juice of $\mathrm{C}$. roseus has been reported to reduce blood 
Rajeshwari Prabha Lahare., Sch Bull, Jan, 2021; 7(1): 1-6

glucose level in normal and alloxan diabetic rabbits [6]. Leaves and twigs of $\mathrm{C}$. roseus have been reported to have hypoglycaemic activity in streptozotocin induced diabetic rats [7]. The demand of $\mathrm{C}$. rosea has been increasing nowadays due to its alkaloid contain mainly used for treatment of cancer [8]. Medicinal plants are used by $80 \%$ of the world population as the only available source of medicines especially in developing countries [9]. While some of these raw drugs are collected in smaller quantities by the local communities and folk healers for local uses, many other raw drugs are collected in larger quantities and traded in the market as the raw material for many herbal industries [10]. Screening of plants for phytochemical is important for finding potential new drugs for therapeutic use. The active principles of many drugs found in plants are secondary metabolites [11]. Aldehydes and phenolic compounds of the plant extract showed significant antimicrobial activities [12]. The beneficial medicinal effects of plant materials typically result from the combinations of secondary products present in the plant. In plants, these compounds are mostly secondary metabolites such as alkaloids, steroids, tannins, phenolics, flavonoids, steroids, resins, and fatty acids which are capable of producing definite physiological action. Antioxidants eliminate these free radicals and protect the body cells from damage. Liu [13] reported that antioxidant activity of plant is due to presence of flavonoids and phenolic acids. Tannins showed strong antioxidant activity [14]. In the present investigation total phenol, flavonoid, tannin and alkaloid content in Catharanthus rosea was analyzed by spectrophometer.

\section{MATERIALS AND METHODS Collection of plant}

Plants material was collected from Durg district, Chhattisgarh, India. Leaf, stem and root parts of plant were washed dried under shade and grinded to make fine powder and extracts were prepared in petroleum ether, chloroform, methanol, benzene and aqueous solvents by using soxhlet apparatus. Extracts were then stored in air tight bottles for further analysis.

\section{Qualitative phytochemical analysis}

Phytochemical analysis was carried out by following the standard protocol of Brindha et al. [15] and Edeoga et al. [16] to detect the presence of cardiac glycoside, terpenoids, steroids, saponins, tannins, flavonoids, alkaloids, quinines, phenols and proteins.

\section{Quantitative analysis}

\section{(a) Determination of total phenol content (TPC)}

The total phenol content in plant extracts was determined by Folin-Ciocalteu method using Gallic acid as standard with slight modification. The reaction mixture consists of $1 \mathrm{ml}$ of extract and $9 \mathrm{ml}$ of distilled water was taken and then add $1 \mathrm{ml}$ of Folin-Ciocalteu phenol reagent the mixture was shaken well. . Then after 5 minutes $10 \mathrm{ml}$ of $7 \%$ sodium carbonate solution was added to the mixture. The standard solutions of gallic acid was prepared in concentrations range of (20, $40,40,60,80$ and 100) $\mu \mathrm{g} / \mathrm{ml}$. The mixture was incubated for $90 \mathrm{~min}$ at room temperature and the absorbance for test and standard solutions were determined against the reagent blank at $550 \mathrm{~nm}$ with an Ultraviolet (UV) /visible spectrophotometer. Total phenol content was expressed as $\mathrm{mg}$ of GAE/gm of extract.

\section{(b) Determination of total flavonoid content (TFC)}

The total flavonoid content in plant extract was determined by Aluminium chloride method. The reaction mixture consists of $0.25 \mathrm{~mL}$ of plant extract in $1.25 \mathrm{~mL}$ distilled water then $\mathrm{NaNO}_{3}$ was added and then the mixture was placed in dark for 6 minutes then 0.15 $\mathrm{ml}$ of $10 \% \mathrm{AlCl}_{3}$ was added and again incubated in dark for 5 minutes. Now $0.5 \mathrm{ml} \mathrm{NaOH}$ and $0.275 \mathrm{ml}$ distilled water was added in the mixture. The set of standard solutions of quercetin was prepared with concentrtaion (20, 40, 60, 80 and $100 \mathrm{mg} / \mathrm{ml})$. The absorbance of standard and the extracts solutions were measured against the reagent blank at $510 \mathrm{~nm}$ with a UV/Visible spectrophotometer. The total flavonoid content was determined from the calibration curve and expressed as milligram of quercetin equivalent (QE) per gram of extracts.

\section{(c) Determination of total tannin content (TTC)}

Folin - Ciocalteu method was used for determination of total tannin content plant extract. About $0.1 \mathrm{ml}$ plant extract was dissolved in $7.5 \mathrm{ml}$ distilled water then $0.5 \mathrm{ml}$ Folin reagent was added in the mixture. Now $1 \mathrm{ml}$ of $35 \% \mathrm{Na} 2 \mathrm{CO} 3$ was added and dilute to $10 \mathrm{ml}$ with distilled water. The mixture was shaken well and kept at room temperature for $30 \mathrm{~min}$. A set of reference standard solutions of gallic acid was prepared with a concentration of $(20,40,60,80$ and 100 $\mu \mathrm{g} / \mathrm{ml})$. Absorbance for test and standard solutions were measured against the blank at $725 \mathrm{~nm}$ with an UV/Visible spectrophotometer. The tannin content was expressed in terms of $\mathrm{mg}$ of $\mathrm{GAE} / \mathrm{g}$ of extract.

\section{(d) Determination of total alkaloid content (TAC)}

The total alkaloid content was expressed as mg of $\mathrm{AE} / \mathrm{g}$ of extract. The plant extract of $1 \mathrm{ml}$ was denatured in DMSO and $1 \mathrm{ml}$ of $2 \mathrm{~N}$ HCL was added and filtered. This solution was transferred to a separation funnel and adds $5 \mathrm{ml}$ of bromocresol green solution and $5 \mathrm{ml}$ of phosphate buffer. The mixture was shaken well with $1,2,3$, and $4 \mathrm{ml}$ chloroform by vigorous shaking and collected in a $10 \mathrm{ml}$ volumetric flask and diluted to the volume with chloroform. The absorbance of mixture was measured in $470 \mathrm{~nm}$.

\section{STATISTICAL ANALYSIS}

The experiments were carried out in three replicates and data were presented as mean \pm S.E. in 
Rajeshwari Prabha Lahare., Sch Bull, Jan, 2021; 7(1): 1-6

Microsoft Excel 2010 for statistical and graphical evaluations.

\section{RESULTS AND DISCUSSIONS}

Phytochemical analysis showed presence of secondary metabolites of biological significance. Plants are used for medicinal purpose since ancient times so it is important to screened plant to known principle active component of plant. Therefore it is vital to evaluate the qualitative and quantitative phytochemical analysis of C. rosea. Several authors have reported the phytochemical analysis of C. rosea such as Bauer [17]. The present study revealed presence of saponin, tannin, terpenoid, flavonoid, cardiac glycoside, alkaloid, steroid, quinones and phenolic compounds whereas protein was found absent. Table 1 showed the phytochemical analysis of leaf, stem and root in different extracts of plant. The quantitative analysis was evaluated for total phenol, flavonoid, tannin and alkaloid content in different extracts of plant. The standard Gallic acid was used for estimation of total phenol content (Fig5). Benzene leaf and stem extract showed highest phenol content with concentration $(0.65 \pm 0.02) \mu \mathrm{g} / \mathrm{ml}$ and $(0.59 \pm 0.01) \mu \mathrm{g} / \mathrm{ml}$ respectively. Petroleum ether extract showed lowest phenol content. Flavonoid is natural antioxidant they play role in plant defence system. Rutin standard was used for estimation of total flavonoid content in different extracts of plant. The highest flavonoid content was found in chloroform leaf extract $(0.62 \pm 0.02) \mu \mathrm{g} / \mathrm{ml}$ followed by benzene stem extract $(0.61 \pm 0.03)$ respectively. Lowest concentration was found in aqueous root extract $(0.38 \pm 0.01) \mu \mathrm{g} / \mathrm{ml}$. The total tannin content was determined with standard tannic acid (Fig7) and found highest in methanol root extract $(1.21 \pm 0.01) \mu \mathrm{g} / \mathrm{ml}$ and lowest in benzene leaf extract $(0.08 \pm 0.05) \mu \mathrm{g} / \mathrm{ml}$. Alkaloids are nitrogenous compounds play role in protection of plant against pathogens and herbivores and widely used as stimulants, pharmaceuticals, poisons and narcotics. The total alkaloid content was estimated with standard quercitin compound (Fig8) and found highest in benzene leaf extract $(0.61 \pm 0.03) \mu \mathrm{g} / \mathrm{ml}$ and stem extract $(0.60 \pm 0.02) \mu \mathrm{g} / \mathrm{ml}$ respectively. Lowest alkaloid content was found in petroleum ether extracts. C. roseus possess carbohydrate, flavonoid, saponin,
Terpenoids, protein and alkaloids [18]. Terpene or terpenoid indole alkaloids have been identified as active anti-cancer, anti-inflammatory and anti-bacterial antiprotozoal and anti-malarial agents in many pharmacological studies $[19,20]$. Tannin acts as antiseptic agent due to presence of phenols and used for the treatment of many infections. Uniyal et al. [21] reported presence of alkaloids, tannins, coumarin, quinine, carbohydrates, flavonoids, triterpenoids and phenolic compounds in C. roseus. Leaves are rich in alkaloids and carbohydrates and flowers in tannins, triterpenoids and alkaloids which are responsible for diabetic and wound healing property [22]. Flowers of C. roseus contain rosinidin an anthocyanidin pigment [23]. Ethanol root extract showed potent antioxidant scavenging effect for C. roseus [24]. In leaf juice of C. roseus vinpocetine like compound was present which showed antioxidant activity similar to flavonoid [25]. It has been studied that methanol and dichloromethane leaf extracts and ethanol root extracts showed antioxidant activity in $\beta$-TC6 cells [26]. Aldehydes and phenolic compounds of the plant extract showed significant antimicrobial activities [27].

\section{CONCLUSION}

The present study demonstrates total phenol, flavonoid, tannin and alkaloid content in leaf, stem and root extracts of Catharanthus rosea. Preliminary phytochemical analysis revealed presence of saponin, tannin, terpenoid, flavonoid, cardiac glycoside, alkaloid, steroid, quinones and phenolic compounds. Protein was found absent. Among five extracts benzene and chloroform shows maximum total phenol, flavonoid, tannin and alkaloid content. This study should be beneficial for development of clinically important natural drugs.

\section{Conflict of interest}

The authors declare no conflict of interests.

\section{ACKNOWLEDGEMENT}

I would like to give thanks to UGC-RGNF fellowship for providing financial support.

Table-1: Phytochemical analysis of Catharanthus roseus from leaf, stem and root parts of the plant

\begin{tabular}{|c|c|c|c|c|c|c|c|c|c|c|c|c|c|c|c|}
\hline \multirow[t]{2}{*}{ Groups } & \multicolumn{3}{|c|}{ Methanol } & \multicolumn{3}{|c|}{ Petroleum ether } & \multicolumn{3}{|c|}{ Choloroform } & \multicolumn{3}{|c|}{ Benzene } & \multicolumn{3}{|c|}{ Aqueous } \\
\hline & $\mathrm{L}$ & $\mathrm{S}$ & $\mathrm{R}$ & $\mathrm{L}$ & $\mathrm{S}$ & $\mathrm{R}$ & $\mathrm{L}$ & $\mathrm{S}$ & $\mathrm{R}$ & $\mathrm{L}$ & $\mathrm{S}$ & $\mathrm{R}$ & $\mathrm{L}$ & $\mathrm{S}$ & $\mathrm{R}$ \\
\hline Saponins & ++ & + & + & - & - & - & + & - & + & - & + & + & ++ & ++ & + \\
\hline Tannins & + & + & - & - & - & - & + & + & - & + & - & - & + & - & - \\
\hline Terpenoids & - & + & - & - & - & - & + & - & - & + & - & + & + & - & + \\
\hline Flavonoids & + & + & - & + & - & - & + & + & - & + & + & - & + & + & + \\
\hline $\begin{array}{l}\text { Cardiac } \\
\text { glycosides }\end{array}$ & - & + & - & - & ++ & + & - & - & + & + & + & - & - & - & + \\
\hline Alkaloids & ++ & ++ & + & + & + & - & + & + & - & ++ & + & + & + & + & + \\
\hline Steroid & + & + & - & + & - & - & + & + & + & + & + & + & + & + & + \\
\hline Quinones & + & + & + & - & - & - & - & + & + & + & - & - & - & - & - \\
\hline Protein & - & - & - & - & - & - & - & - & - & - & - & - & - & - & - \\
\hline Phenol & + & + & + & - & + & - & + & - & + & + & + & + & + & + & - \\
\hline
\end{tabular}


Presence $=(+)$, Absent $=(-)$

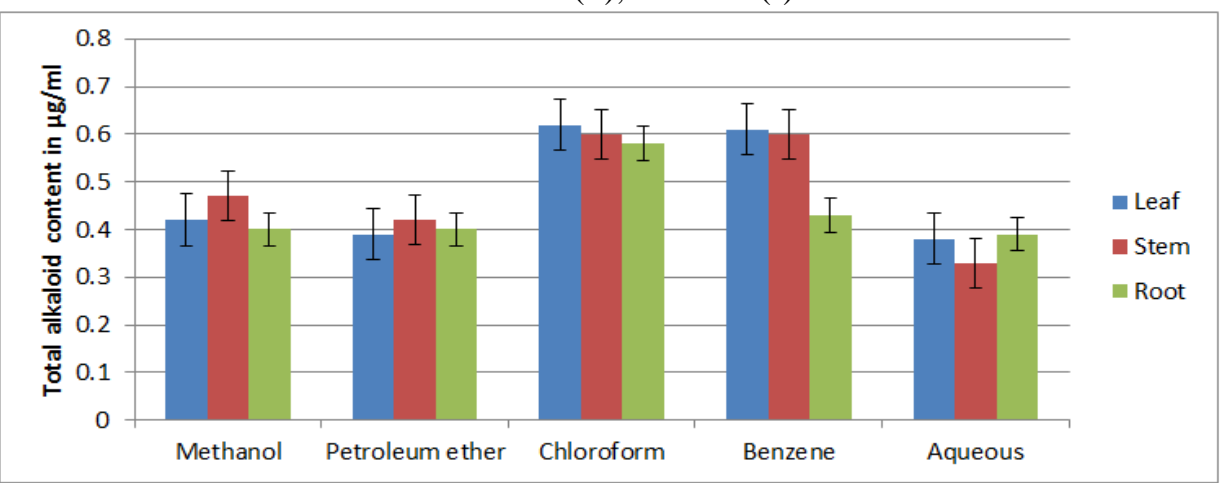

Fig-1: Showing total alkaloid content in $\mu \mathrm{g} / \mathrm{ml}$ in leaf, stem and root extracts of $\mathrm{C}$. rosea.

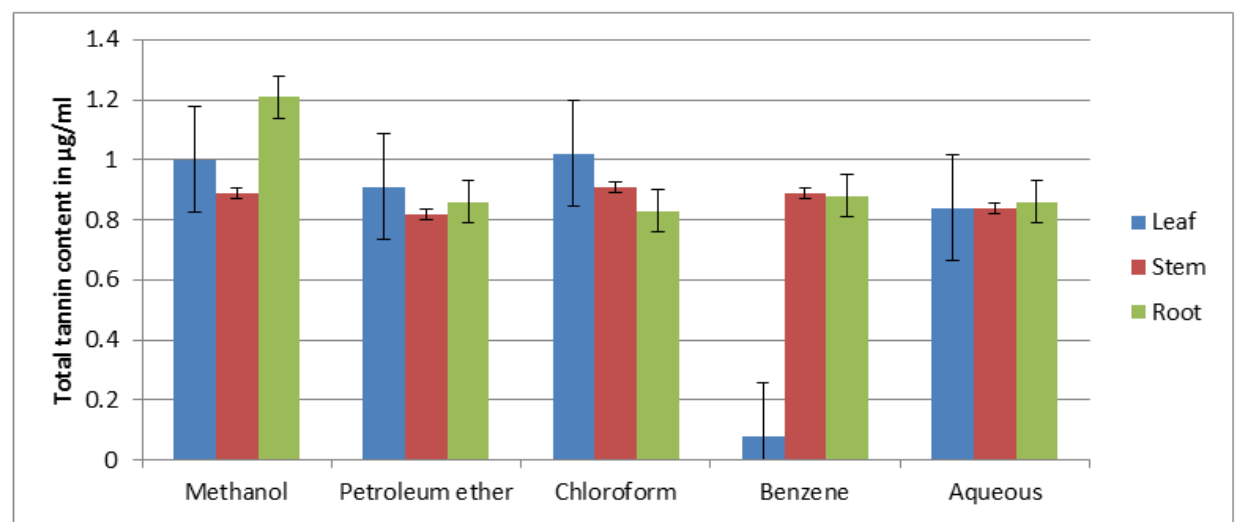

Fig-2: Showing total tannin content in $\mu \mathrm{g} / \mathrm{ml}$ in leaf, stem and root extracts of $\mathrm{C}$. rosea.

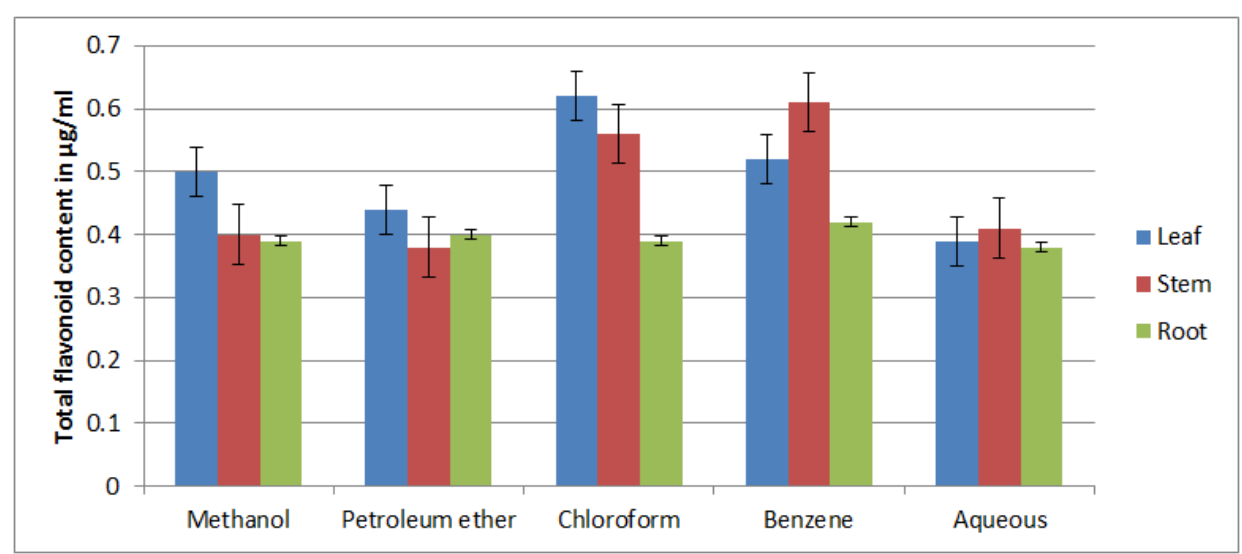

Fig-3: Showing total flavonoid content in $\mu \mathrm{g} / \mathrm{ml}$ in leaf, stem and root extracts of C. rosea

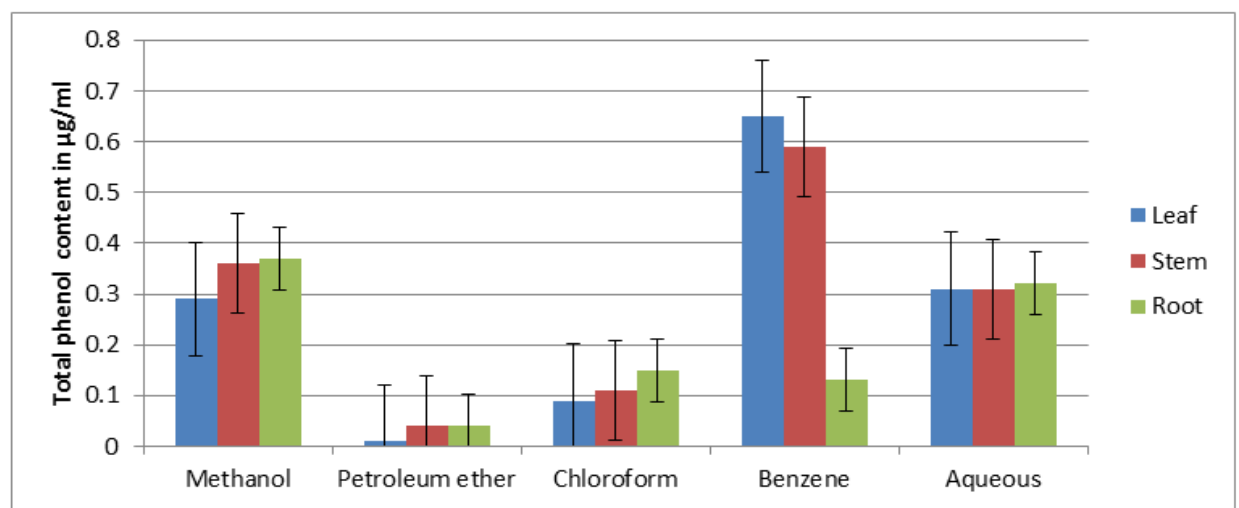

Fig-4: Showing total phenol content in $\mu \mathrm{g} / \mathrm{ml}$ in leaf, stem and root extracts of $\mathrm{C}$. rosea. 


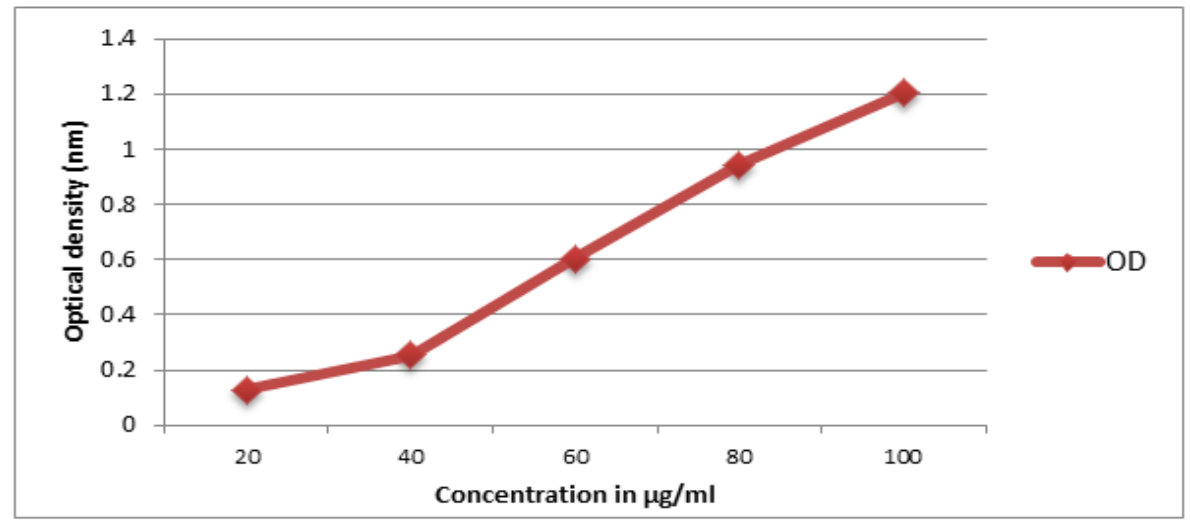

Fig-5: Showing standard curve for phenol (Gallic acid)

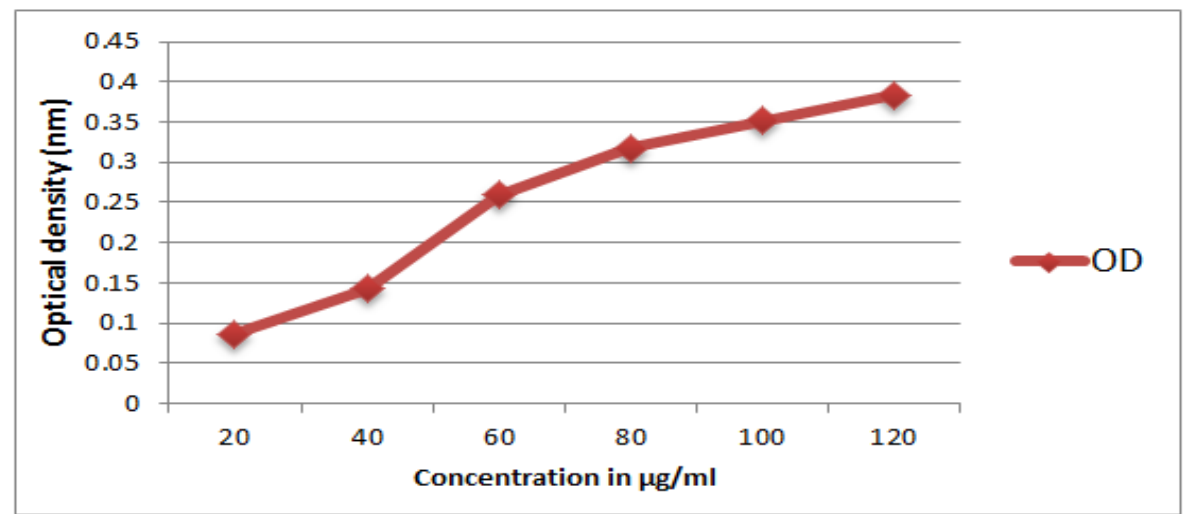

Fig-6: Showing standard curve for flavonoid (Rutin)

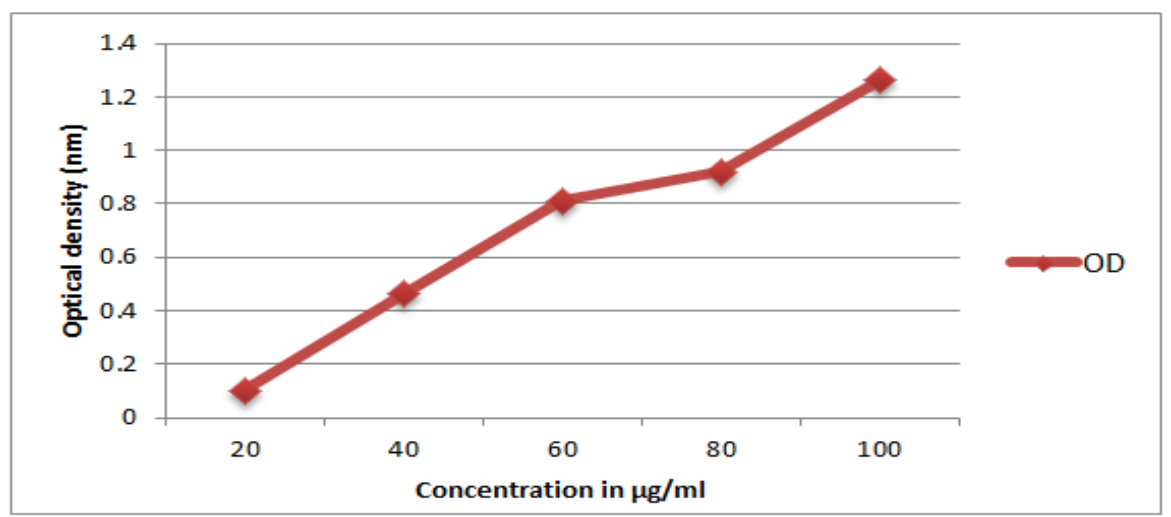

Fig-7: Showing standard curve for tannin (Tannic acid)

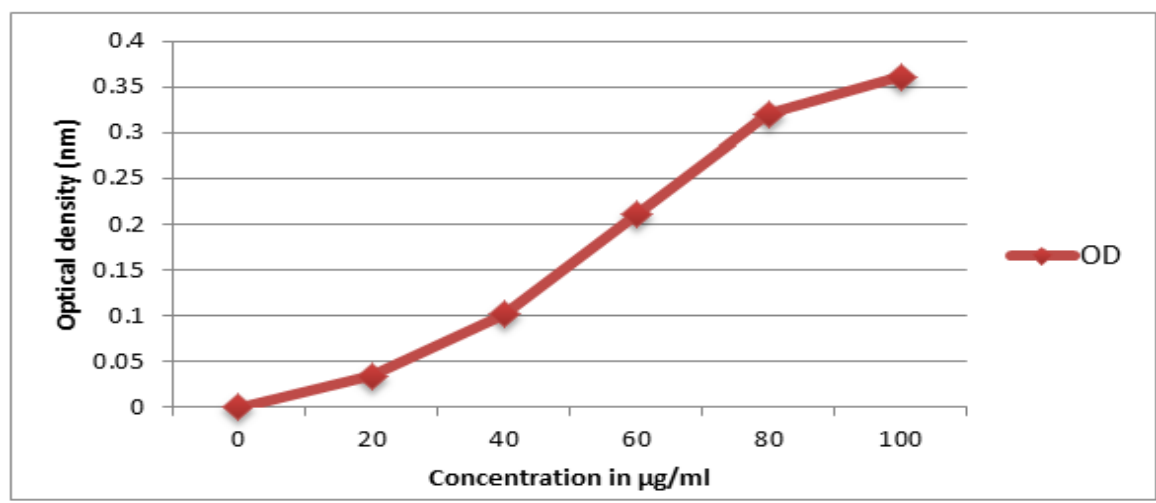

Fig-8: Showing standard curve for alkaloid (quercitin) 
Rajeshwari Prabha Lahare., Sch Bull, Jan, 2021; 7(1): 1-6

\section{REFERENCES}

1. Jaleel, C. A., Gopi, R., Lakshmanan, G. A., \& Panneerselvam, R. (2006). Triadimefon induced changes in the antioxidant metabolism and ajmalicine production in Catharanthus roseus (L.) G. Don. Plant Science, 171(2), 271-276.

2. Jordan, M.A. Thrower, D., Wilson, L. (1991). "Mechanism of inhibition of cell proliferation by Vinca alkaloids," Cancer Research, 51(8): 22122222.

3. Kulkarni, R. N., Baskaran, K., Chandrashekara, R. S., \& Kumar, S. (1999). Inheritance of morphological traits of periwinkle mutants with modified contents and yields of leaf and root alkaloids. Plant Breeding, 118(1), 71-74.

4. Cowley, R. C., \& Bennett, F. C. (1928). "Vinca rosea," Australian Journal of Pharmacy. 9; 61.

5. Pillay, P. P., Nair, C. P. M., \& Santi Kumari, T. N. (1959). Lochnera rosea as a potential source of hypotensive and other remedies. Bulletin of Research Institute of the University of Kerala, 1, 51-54.

6. Nammi, S., Boini, M. K., Lodagala, S. D., \& Behara, R. B. S. (2003). The juice of fresh leaves of Catharanthus roseus Linn. reduces blood glucose in normal and alloxan diabetic rabbits. BMC complementary and Alternative Medicine, 3(1), 4.

7. Singh, S. N., Vats, P., Suri, S., Shyam, R., Kumria, M. M. L., Ranganathan, S., \& Sridharan, K. (2001). Effect of an antidiabetic extract of Catharanthus roseus on enzymic activities in streptozotocin induced diabetic rats. Journal of Ethnopharmacology, 76(3), 269-277.

8. Lahare, R.P., Yadav, H.S., Dashhare, A., Bisen, Y.K. (2020). An Updated Review on Phytochemical and Pharmacological Properties of Catharanthus rosea. Saudi Journal of Medical and Pharmaceutical Sciences, 6(12), 759-766.

9. Hashim, H., Kamali, E.L., \& Mohammed, Y. (2010). Antibacterial Activity and Phytochemical screening of Ethanolic Extracts Obtained from Selected Studanese Medicinal Plants. Current Research J. research, 51(8), 2212- 2222.

10. Uniyal. S.K., Singh, K.N., Jamwal, P., \& Lal, B. (2006). Traditional use of medicina.

11. Ghahi, A. (1990). Introduction to pharmacognosy, Ahmadu Bello University press, Ltd. Zaria, Nigeria, 45-47.

12. Lai, P. K., \& Roy, J. (2004). Antimicrobial and chemopreventive properties of herbs and spices. Current medicinal chemistry, 11(11), 14511460.

13. Liu, Y. W., Han, C. H., Lee, M. H., Hsu, F. L., \& Hou, W. C. (2003). Patatin, the tuber storage protein of potato (Solanum tuberosum L.), exhibits antioxidant activity in vitro. Journal of Agricultural and Food Chemistry, 51(15), 4389-4393.
14. Cai, Y. Z., Sun, M., Xing, J., Luo, Q., \& Corke, H. (2006). Structure-radical scavenging activity relationships of phenolic compounds from traditional Chinese medicinal plants. Life sciences, 78(25), 2872-2888.

15. Brindha, P., Sasikala, B., Purushottaman, K.K. (1981). BMEBR, 3(1), 84-96.

16. Edeoga, H.O., Okwu, D.E., Mbaebie, B.O. (2005). Afric J Biotechn, 4(7), 685-688.

17. Bayer, A. W., Kirby, W. M. M., Sherris, J. C., \& Turck, M. (1966). Antibiotic susceptibility testing by a standardized single disc method. Am J clin pathol, 45(4), 493-496.

18. Tamizhazhagan, V., Pugazhendy, K., Sakthidasan, V., \& Jayanthi, C. (2017). Preliminary screening of phytochemical evaluation selected plant of Pisonia alba. IJ Biol. Research, 2(4), 63-66.

19. Mahato, S. B., \& Sen, S. (1997). Advances in triterpenoid research, 19901994. Phytochemistry, 44(7), 1185-1236.

20. Asase, A., Akwetey, G. A., \& Achel, D. G. (2010). Ethnopharmacological use of herbal remedies for the treatment of malaria in the Dangme West District of Ghana. Journal of ethnopharmacology, 129(3), 367-376.

21. Uniyal, G.C., Bala, S., Mathur, A.K., Kulkarni, R.N. (2001). Symmetry C18 column: A better choice for the analysis of indole alkaloids of Cathranthus roseus. Phytoche Anal, 12, 206-10.

22. Zhou, M.L., Shao, J.R., Tang, Y.X. (2009). Production and metabolic enginnering of terpenoid indole alkaloids in cell cultures of the medicinal plant Catharanthus (L)G Don (Madagascar periwinkle). Biotechnol Appl Biochem, 52, 313-23.

23. Gajalakshmi, S., Vijayalakshmi, S., \& Devi, R. V. (2013). Pharmacological activities of Catharanthus roseus: a perspective review. International Journal of Pharma and Bio Sciences, 4(2), 431-439.

24. Alba Bhutkar, M. A., \& Bhise, S. B. (2011). Comparative Studies on Antioxidant Properties of Catharanthus Rosea and Catharanthus. International Journal of Pharmaceutical Techniques, 3(3), 1551-1556.

25. Patel, Y. (2011). Evaluation of hypolipidemic activity of leaf juice of Catharanthus roseus (Linn). Acta Poloniae Pharmaceutica - Drug Research, 68(6), 927-935.

26. Stanković, S. M., Ćurčić, G. M., Žižić, B.J., Topuzović, D.M., Solujić, R.S. and Marković, D.S. (2011). "Teucrium plant species as natural sources of novel anticancer compounds: Antiproliferative, proapoptotic and antioxidant properties.'Int J Mol Sci 12 4190-4205

27. Lai, P.K., \& Roy, J. (2004). Antimicrobial and Chemo preventive properties of herbs and spices. Curr Med Chem, 11, 451-1460. 